\title{
Ethics, collective health, qualitative health research and social justice
}

\author{
Ética, Saúde Coletiva, pesquisa qualitativa em saúde e justiça social
}

Iara Coelho Zito Guerriero ${ }^{1}$

Fernando Peñaranda Correa ${ }^{2}$

Instituto de Medicina Tropical, Universidade de São Paulo. Av. Dr. Eneas Carvalho de Aguiar 470, Centro. 05403-000 São Paulo SP Brasil. iarag@usp.br

${ }^{2}$ Facultad Nacional de Salud Pública, Universidad de Antioquia.
Abstract The scientific field is characterized by the disputes about the delimitation of the field problems, methods and theories that can be considered scientific. The recognition that it is not neutral, that a researcher is a moral subject, and its practices are moral ones, entail that moral reflections, that is, ethics, should be a core process of every researcher. Therefore ethics is not a heteronomous issue, and cannot be reduced to guidelines. In the first part of this article we examine the need to develop an open approach to the construction of guidelines in a plural scientific field that must take into account diverse paradigms, which implies different values. The Brazilian process of writing guidelines on research ethics for social science and humanities in the context of the Ministry of Health will be discussed as an example. In the second part we expand the analysis of research ethics posing a perspective that integrates qualitative research, social justice and discipline trends. In the final considerations we explore the possibility that research ethics is better discussed taking into account the ontology, epistemology and political values rather than one specific methodological approach or from a dichotomic perspective between biomedicine versus social science and humanities. Key words Research ethics, Social justice, Qualitative research, Bioethics
Resumo O campo científico é caracterizado por disputas sobre a delimitação do campo dos problemas, métodos e teorias que podem ser considerados científicos. O reconhecimento de que o campo científico não é neutro, que o pesquisador é um sujeito moral, e que suas práticas são morais, obriga à reflexão moral, ética, que é central para todo investigador. Portanto ética não é uma questão heterônoma e não pode ser reduzida às diretrizes. $\mathrm{Na}$ primeira parte deste artigo examinamos a necessidade de se desenvolver uma abordagem inclusiva para a construção de diretrizes num campo científico plural, que deve considerar os diversos paradigmas, que implicam em diferentes valores. O processo brasileiro de elaboração de diretrizes éticas para pesquisas em ciências humanas e sociais no contexto do Ministério da Saúde será discutido como exemplo. Na segunda parte ampliamos a análise sobre ética nas investigações, propondo uma perspectiva que integra pesquisa qualitativa, justiça social e tendências disciplinares. Nas considerações finais, exploramos a possibilidade de que ética em pesquisa é melhor discutida considerando a ontologia, a epistemologia e os valores políticos ao invés de uma abordagem metodológica específica ou a partir de uma perspectiva dicotômica como biomedicina e ciências humanas e sociais.

Palavras-chave Ética em pesquisa, justiça social, pesquisa qualitativa, bioética 


\section{Introduction}

Guidelines on research ethics frequently adopt a specific definition about science and about ethics, without explicitly recognizing that there are many ways to define these concepts. In addition, the aim to write guidelines on research ethics for all disciplines may result in inadequacies. There is no research conducted in a vacuum. Gender, age, socioeconomics situations and the specific academic community in which each researcher participated define the researcher's point of view. The way each person deals with this set of aspects results in a specific position, from where each one understands the world, including the research process. The word "research" has different meanings according to each specific academic community and the paradigms adopted ${ }^{1}$. The scientific field can be defined as the locus of a political struggle for scientific domination, assigns each researcher, as a function of his position within it, his indissociably political and scientific problems and his methods - scientific strategies which, being expressly or objectively defined by reference to the system of political and scientific positions constituting the scientific field, are at the same time political strategies ${ }^{2}$. Therefore, the definition about what can be considered research cannot be imposed by guidelines for research ethics, because it is exactly what is at stake in the scientific field. So, when a guideline for research ethics assumes one specific definition about research, it crystalizes one definition of science over others, reinforcing the hegemony of one specific paradigm, which in the health field is the positivist paradigm.

The recognition that the scientific field is not neutral, and that each researcher has interests, implies the ethical responsibility to explicitly state these interests. In the first part of this article we examine the need to construct an open approach to the construction of guidelines on research ethics in a plural scientific field that must take into account diverse paradigms which implies different values. The Brazilian process of writing guidelines on research ethics for social science and humanities (SSH) in the context of the Ministry of Health will be discussed as an example. In the second part we expand the analysis of research ethics posing a perspective that integrates qualitative research, social justice and discipline trends. In the final considerations we explore the possibility that research ethics is better discussed considering the ontology, epistemology and political values rather than one specific approach methodological or big areas such as biomedicine versus SSH.

\section{The challenge to write guidelines \\ on research ethics for social science and humanities (SSH) in Brazil}

For almost 20 years Brazilian researchers have been stating the need of specific guidelines for SSH, because guidelines based on biomedical research, specifically based on paradigms positivists, are not adequate for all fields. These claims became better organized in 2007, when the Health Department of São Paulo City published a report ${ }^{3}$ prepared with the participation of national associations of researchers in $\mathrm{SSH}$, the Ministry of Health and international institutions. It was the first Brazilian document produced with the collaboration of scientific associations, and that stated the need of guidelines for research ethics, specific for SSH. This movement continued to grow with the motion passed at the Brazilian Society for the Advancement of Science (SBPC), Final Declaration of the IV Ibero-American Congress of Qualitative Health Research (2010), the letters posted in response to the public consultation of Resolution 196/96 $6^{4}$ and in 2013 the formation of a Forum of Humanities and Social Sciences, composed by national research associations and graduate studies in these areas. All this movement, at the same time, political and epistemological, resulted that in 2012, the Resolution 466/12 $2^{5}$ stated the need of guidelines for $\mathrm{SSH}$ research. The National Commission on Research Ethics (CONEP), that is one commission of National Health Council/ Ministry of Health (CNS), organized a working group (WG) to write this resolution. This WG is made up by 18 national associations on research in SSH, representatives of Ministry of Health and of CNS and it is coordinated by CONEP. The first meeting was in August 2013, with biweekly meetings, and the WG presented its first proposal to CONEP in October 2014. The answer given by $\mathrm{CONEP}^{6}$ makes clear the dispute between biomedicine and $\mathrm{SSH}$ researchers and the aim to maintain the hegemony of positivist paradigm ${ }^{7}$.

Since the first meeting the differences were explicitly stated, highlighting that The preparation of guidelines for research ethics with human beings is a political process, characterized by epistemological disputes and by the fighting for the power to stablish the definition of science ${ }^{1}$. SSH researchers work based on different paradigms, research different themes in different areas, and they are guided by different values. 


\section{Scientific field, paradigms of science and its ethical implications}

The paradigms are defined, legitimated, articulated and reviewed in the scientific field. In this text, we make a brief comparison between different paradigms explaining the ethical implications of each. The focus on paradigms comparison implies seek similarities between authors working in the same paradigm, even if among them there are also differences that will not be discussed in this text.

Guba and Lincoln ${ }^{8}$ and Lincoln et al. ${ }^{9}$ consider that the paradigm is axiomatic nature and therefore are accepted simply on faith (however well argued); there is no way to establish their ultimate truthfulness ${ }^{8}$. For these authors, the paradigm definition includes three interrelated aspects ${ }^{9}$ : ontological , epistemological and methodological. Very briefly, according to these authors $^{8}$, the ontological question is related to the nature of reality and therefore identifies what can be known. The epistemological question deals with the nature of the relationship between the knower and the phenomenon to be known ${ }^{8}$. The methodological issue relates to how to approach the phenomenon to be investigated ${ }^{8}$. It should be emphasized that the method to be used is intrinsically related to disciplines and specific theoretical references. An example may clarify the interdependence of these three aspects: one who believes that there is a reality independent of the observer, collect the data adopting procedures to avoid contaminating them and their outcome aims at drawing up laws. On the other hand, one who believes that reality is constructed in the interaction among different subjects, including the researcher and the research participants, does not consider possible their exemption, assumes that the material is generated during the research process and, because there are different social realities that are human constructions and may change over time, the possible knowledge to be built is always partial and temporary. Interestingly, the ontological and epistemological issues overlap in this second example, because the researcher is (or becomes) admittedly part of the phenomenon to be studied ${ }^{1}$.

In this text the ontological and epistemological differences among the positivists, critical, constructivist and participative paradigms, as discussed by Lincoln et al. ${ }^{9}$ are discussed focusing on their ethical implications ${ }^{1}$.
Ethics and paradigms of science

In positivist and post positivist paradigms the ethical dimension is considered extrinsic to the research process. The researcher considers himself impartial and his proposal is to produce neutral scientific knowledge. It is not consider a researcher's responsibility to use the results of their research to benefit the participants and their community. On the contrary, acting on the research results is considered advocacy or as a manifestation of subjectivity, constituting a serious risk of jeopardizing the desired objectivity, which is considered essential for scientific rigor?. The assumed ontological position, naive realism, favors conducting research in which participants receive technical and partial information. Because the objective is to know "how things really happen" or because the research is being carried out by a "greater good" 8 . It is in this context that emerge the need for external ethical evaluation, through committees that evaluate the project based on guidelines on research ethics.

In critical and participatory paradigms ethical issues are considered intrinsic to the research process. The researcher considers the values of the participants in their historical context and aims to understand how issues such as gender, ethnicity, socioeconomic status are built and maintained. The researcher includes among its responsibilities to inform participants that the situation in which they live is socially constructed and therefore can be modified towards a more just society. Researchers intend that the participants take an active role in defining the issues to be investigated and the dissemination of research results, in and out of their ${ }^{9}$ community, in addition to the dissemination to the scientific community. Critical and participatory paradigms have thus an emancipatory proposal, for which the free and informed consent (IC) process is crucial $^{8}$ for the success of the proposal itself.

Given the specificities of each paradigm and its ethical implications, it is clear that the attitude of the researcher is strongly influenced by the paradigms assumed. These differences are explicit if we consider what motivates the scientific production and the researcher's position during the research process ${ }^{1}$.

\section{Motivation}

In positivist and post-positivist paradigms, the scientific knowledge is a value in itself and therefore the responsibility of the researcher ends with the publication of the results to the scientific community. In critical and participatory para- 
digms, scientific knowledge is a tool for emancipation, and it is the final goal of researchers.

\section{Researcher's position}

For critical and participatory paradigms, the construction of knowledge focuses on the production of meaning that occurs in human interaction, which implies that knowledge cannot be separated from who produces $\mathrm{it}^{8}$ and therefore, objectivity, as understood by positivist and post -positivist, is not possible.

The assumption that knowledge is produced in the intersubjective relationship implies that the relationship established between researcher and participants is necessarily a relationship between two subjects. In no time the research participant is transformed into "object" of study ${ }^{10}$. This is a very important implication for research in critical and participatory paradigms in which to turn the other an object prevents the possibility to construct knowledge.

The researcher works from a specific point of view and therefore the result of this work, the production of scientific knowledge, is not neutral, but is deeply committed to certain interests.

Clearly the ethical issues that arise in researches conducted in positivist and post- positivist paradigms are radically different from those that are present in critical and participative paradigms. The values assumed by researchers are the fundamental differences.

\section{There are no good judges}

Faced with this paradigmatic diversity, which in SSH coexist without succeeding one another, it is easy to identify the dispute among different areas and, within each, among different researchers. In particular, if we consider that disputes that characterize the scientific field, including the delimitation of the field problems, methods and theories that can be considered scientific ${ }^{2}$, aimed to defend the definition most likely to enable him[researcher] to occupy the dominant position in full legitimacy, by attributing the highest position in the hierarchy of scientific values to the scientific capacities which he personally or institutionally possesses ${ }^{2}$

Therefore, the struggle among researchers, including among SSH researchers, is a permanent situation that permeates the writing of guidelines for research ethics. In Bordieau ${ }^{2}$ words: Because the definition of the criteria of judgment and the principles of hierarchisation is itself at issue in a struggle, there are no good judges, because there is no judge who is not also a party to the dispute."

\section{Qualitative research, disciplines, social justice and bioethics}

If the central concern of modern ethics is justice $^{11}$ and judgments on justice are moral ones ${ }^{12}$, then there is a relationship between ethics, morality and justice that must be taken into consideration when thinking about research ethics. Following Pieper ${ }^{13}$, morality can be understood as the norms and values that are self-imposed and binding in the form of obligations or prohibitions that deserve general recognition, but also as a set of moral judgments made by people or groups of people ${ }^{14}$.

Morality then, is socially and culturally rooted, and is developed through primary and secondary socialization during the lifetime of each person $^{13-15}$. Corresponds to the individual's capacity ${ }^{16}$ to feel guilt, shame, and indignation, as internal sanctions and compelling feelings when a person is faced with transgressions and moral dilemmas such as injustices ${ }^{14,17}$.

How can it be approached then the analysis of research ethics on qualitative health research? Maybe to start the discussion it is best to take into consideration the usual distinction between qualitative and quantitative research. Second it is needed to reflect on different perspectives of social justice as distinct moral references that clash in contradictions and conflicts. Third it must be recognized that there is not a unique understanding of bioethics, because there are more than one theoretical and political point of view, which generate confrontations and conflicts. Finally thinking about qualitative health research, bioethics and social justice must be done in the concrete context of a specific discipline perspective.

\section{Beyond qualitative and quantitative} research dichotomy

A dichotomous perspective of research is sometimes expressed by some scholars, pointing an antagonistic point of view between qualitative and quantitative trends in health research. It is useful to analyze this dichotomy to make a complementary approach to the one done above with regard to the dispute between biomedical, positivist model, and SSH.

For these researchers the difference is justified because the kinds of "objects" are distinct, so for different kind of objects there would be different methods, following an Aristotelian point of view. From an epistemological perspective qualitative research is seen by others as a critical movement that goes in odds with a positivistic 
research that embraces values such as objectivity and neutrality, due to a complete distinction between object and subject, and which purpose's is the construction of knowledge ${ }^{18}$. So political and moral values, such as social justice are taken as "external" or "extra-scientific" accounts ${ }^{19}$.

In contrast with these values, critical qualitative researchers argue that science is always value laden, and therefore there is no neutrality, nor a complete distinction between objet and subject because reality is a social construction ${ }^{15}$. Research is always the product of concrete interests, and if this is true, a legitimate interest in research could be human emancipation, and social change ${ }^{20}$. Some critical scholars then, state that research must pursue, in a direct way, social justice, which means a political involvement with social action and transformation ${ }^{21}$. Lyotard ${ }^{22}$ states that scientists, as human beings, are practical subjects, and that for practical subjects, justice comes above truth.

As has been said in this paper, there are multiple paradigms and theoretical trends from which research is done. There are no sharp limits between paradigmatic stances, even though there are different epistemological and political points of view that come into conflict and contradiction. In a plural scientific field, crossed by hierarchies and power relations, were multiple moral perspectives come in confluence, maybe a dichotomous qualitative - quantitative point of view of research is reductionist. A more broad and comprehensive point of view could be taking into account the values which they hold, and one of these values is social justice.

\section{The diverse meaning of social justice}

As in research, there are multiple theories and ways of understanding social justice which respond to different moralities. For the purpose of this paper we would like to identify three theoretical and political trends of social justice. Even though there are no sharp limits between these three trends, this classification will be used to identify some characteristics which are useful for thinking in diverse perspectives of social justice.

One trend is the one which backs neoliberal basic values. Following Robert Nozick, there should be a minimum state responsible to protect people's "natural" rights, that is, property, freedom and physical integrity. He criticizes distributive justice, because taking away property (taxation) to redistribute it according to any criteria is a violation of rights, therefore is im- moral $^{23}$. Neoliberal political and social reforms supported in this moral perspective have pulled governments to decrease the state provision of goods and services, to expand the participation of market players and develop public policies founded on focalization of resources to "vulnerable" people, which have the worst conditions to afford social risks ${ }^{24}$.

There would be a second trend, in which we include the distributive perspectives of social justice, such as Rawls' fairness theory ${ }^{25}$, or the Sen's capabilities approach ${ }^{26,27}$. From this point of view a just society should guarantee an appropriate distribution of the benefits and burdens of social organization and production, so that everyone can have opportunities to live the life they merit, that is, a life with dignity ${ }^{25}$. This distribution includes such goods as rights, liberties, powers, opportunities, income, wealth, and selfrespect ${ }^{25}$ or capabilities understood as social and personal opportunities $^{26}$. Liberal redistribution is a combination of two principles, freedom and equality, which implies the state protection of negative right "to be", and the "positive" right to do, which needs economic, social and cultural rights to be guaranteed $^{24}$. From these approaches important liberal critiques to capitalism are made at a national and international level, but they look for modifying the socio-economic system founded in the market without considering changing it for another one.

A third trend could group together those critical Marxists, neo-Marxists or other leftist positions that assume poverty as a cause of capitalism, and particularly neoliberalism that has widened differences between reach and poor among people and countries. Inequity, from this point of view, is a product of power relations that controls property, material wealth, and the possibilities to expand human and social identities and aspirations, generating domination that intersect social classes, gender and ethnicity ${ }^{24}$. Then, social justice implies a change of the current development model founded in capitalism.

\section{Bioethics: multiple and politicized}

Confrontations in bioethics can also be seen between different theoretical and political stances. Principialist bioethics, named Anglo-Saxon bioethics by some Latin-American bioethicists $^{28,29}$, has been the dominant perspective. Several arguments have been made confronting principialist bioethics. One questioning has to deal with plurality of moralities. Principial- 
ist bioethics moral point of view is one among different moralities. There is not a universal morality. Stablishing norms and values, as fixed principles, for assessing "good research" and determining appropriate procedure brings the following questions: What is good research? What is an appropriate procedure? ? $^{29}$.

A second questioning has to deal with the priority given to the principle of autonomy that has driven bioethics towards an individualist perspective ${ }^{28}$ with a strong impairment for social and community approaches ${ }^{30}$. For this reason, Macena and Veloso ${ }^{29}$ state that justice principle has a minor role and a restricted meaning.

There is a third critique, which questions a "neutral" bioethics which doesn't take into account the socio - economic condition of countries and people. Garrafa ${ }^{28}$ states that doing research in countries with great socio-economic disparities, with a low research development, low educational level of population, big access barriers to health services, high problems of poverty, exclusion and human right violation, is different to the research done in countries with higher quality of life.

From these critiques Garrafa ${ }^{28}$ points out two routes for bioethics. The first is to recognize that there is not a neutral bioethics, which means diversity of perspectives. One of these perspectives can be opened to a commitment with social justice, which implies that bioethics must pursue the diminishment of injustices, and that people and communities must have a direct benefit of research products. From Garrafa's point of view, bioethics must work to promote an alternative social development model to neoliberalism that can reduce injustices, inequalities and exploitation between countries and people, and better ways of sharing benefits and burdens of development, as well as better ways of social organization.

The second route is to politicize bioethics. Following Rawls ${ }^{25}$, it is not possible to negotiate moral disparities and conflicts in a moral sphere. The confrontation between different moralities must be settled at a political level. Garrafa ${ }^{28}$ challenges the imposition of a vision of bioethics that comes from central countries, and instead talks about a dynamic and politicized bioethics that can take into account historic plurality, human dignity and social justice.

\section{Social justice and bioethics \\ from a discipline perspective}

As has been pointed before it can be said that there are scientific paradigms that hold ethics from an intrinsic point of view and others from an extrinsic one. In a similar way, there are discipline perspectives or trends that assume social justice from an explicit point of view and others don't. As Venkatapuram and Marmot ${ }^{31}$ says, every discipline trend is rooted in moral values, and indeed in assumptions about social justice. Not reflecting on the moral values that support the theory and practice of disciplines can maintain or increase injustices ${ }^{32}$. The assumptions about social justice that support a given discipline trend has an important impact on theory and practice of $\mathrm{it}^{31}$.

So looking research in public health and epidemiology, as an example, there could be many trends and stances taking into account different perspectives of social justice, research paradigms and bioethics. We would like to distinguish at least three different levels of reflection, commitment and involvement with respect to social justice, following Venkatapuram and $\mathrm{Marmot}^{31}$ analysis on the place of social justice in epidemiology.

A first level could be those discipline trends that assume a neutral, objectivistic and realistic position, usually related to a positivistic paradigm in which social justice and political involvement are understood as "extracientific" interests, so there is not an explicit description of the researcher's position with regard to these issues ${ }^{31}$. These positions can match with what has been described as "neutral" bioethics which is extrinsic to research. As Bauman ${ }^{16}$ states, this is a heteronomous perspective of ethics, because morality lies, essentiality, in the fulfillment of bioethical codes, and the moral reflection (which includes social justice) is not a core issue in the research process and concerns of the researcher.

Some trends of mainstream utilitarian public health, which have supported neoliberal health systems reforms in which health services are taken as a merchandise that is traded in a market sphere, can be placed in this first level.

A second level could be those trends that take social justice as an important issue for their discipline, and explicitly states their position toward it. As Venkatapuram and Marmot ${ }^{31}$ argues, the position assumed towards social justice will determine the scope of the discipline, both, from an ontological and epistemological point of view. From an ontological perspective, the discipline 
object's changes, that is, what is to be researched. From an epistemological perspective it changes the methodological approaches. These researchers think their approach to their discipline is not descriptive as in the first level, because they have an explicit moral commitment and responsibility towards social justice which guides the construction of knowledge. In the case of epidemiology, these commitments, supported on a concrete theory of social justice (the capability approach) gives a different grounding for finding causes, distribution patterns and consequences of illness ${ }^{31}$. In this way, these scholars have, in their words, a wider reference for making good science, with an ethical commitment. So a better way of understanding illness causes can give better information for the construction of policies at a political level, which goes beyond the scope of research. Even though there is a critical position in these types of trends, recognizing the influence of values and morality in the action of researchers, they maintain the ideals of validity and good empirical epidemiological research. Some qualitative research works could be located here within Venkatapuram idea of "good" science. Lyncoln ${ }^{33}$ for example, proposes seven criteria for judging the goodness of qualitative research that consider epistemological and ethical aspects. Among them, it is included how the scientific knowledge contributes to the human development.

At this level of involvement, it can be found important critiques to neoliberalism and capitalistic mode of production, such as those found on the work done by the WHO's Commission on Social Determinants of Health ${ }^{34}$, which adhere to Sen's capability approach of social justice ${ }^{35}$. But their involvement on social justice is centered on producing better and wider scientific knowledge that can be used at the political spheres. These scholars are not thinking on changing the capitalist model of development for another one, but instead, on introducing modifications that can make the system fairer.

Venkatapuram and Marmot ${ }^{31}$ just identifies these two possibilities, but there could be at least another level of involvement with regard to social justice. Some trends of public health coming from Latin American's social medicine ${ }^{35}$, collective health $^{36}$ and critical epidemiology ${ }^{37}$, believe their commitment to social justice must include not only the construction of academic knowledge, but a direct involvement in social justice. There should be direct benefits for the people involved in research, and research should be planned and developed having as a central purpose the allevi- ation of injustices. Action should be done both at a community and structural levels. It should be prioritized the construction of knowledge useful for people who participate in the research, so that they can understand, in a more comprehensive way, the conditions of exploitation and injustices in which they live, so that they can act in a more productive way. Here the political involvement of the researcher is mandatory. Here the discipline locates towards social justice in a way that matches with those critical trends of bioethics committed with the diminishment of injustices and oppression $^{28}$. For these trends of public health and for collective health, ethical reflection is a central and intrinsic issue of the research process, and of researcher concerns.

\section{Final considerations}

The dispute between biomedical, positivist model, and SSH, with its different paradigms involved, is evident. It is fundamental to have guidelines on research ethics that recognize the existence of different scientific paradigms, its related values and to respect this diversity. For now, when these differences are not even recognized, it is important to establish specific guidelines on research ethics for $\mathrm{SSH}^{38}$. The Brazilian situation expresses this dispute. The text proposed by the WG was strongly criticized by $\mathrm{CONEP}^{6}$, which assumes the positivist conception that there is just one correct point of view, and assumes an authoritarian position. It is worth to present two points proposed by the WG SSH and rejected by CONEP: 1.the scientific merit should be evaluated by Master's Thesis and Doctoral Dissertation Committees; funding agencies, research committees, among others. Research Ethics Committees (RECs) should review the ethical aspects involved in the research. 2. The criteria to evaluate the level of risk must be specific to $\mathrm{SSH}$, and the concept of risk itself should be deeply discussed.

Moving to the WG made up mainly by SSH researchers, this dispute can be even harder. If there is agreement in this WG that knowledge is produced in a intersubjective relationship, the aim to benefit research participants and their community is far from reaching a consensus. The epistemological and political disputes are always there, which constitute themselves in a challenge to write a single resolution for research ethics to $\mathrm{SSH}^{1,39}$.

Given the complexity of this situation, we explore the possibility that what should be considered are the values that underline every research 
process. Can a social science or humanities research process be conducted in a way that damage research participant, intentionally or not? Can a biomedical research project benefit research participants? We assume that both answers are "yes". A good example is the community based participatory research (CBPR) that adopts as one of its principles that the integration of knowledge and action should result in mutual benefit of all partners ${ }^{40}$. As a research guidance which can use both quantitative and qualitative methods, and in which social sciences and humanities researchers can work with biomedical researchers, it overcomes the duality between qualitative versus quantitative and between social sciences and humanities versus biomedicine, because all of them have the possibility to be conducted in a respectful way and with the intention to benefit research participants and their communities.

Guba and Lincoln" affirmed "both qualitative and quantitative methods may be used appropriately with any research paradigm. Questions of method are secondary to questions of paradigm, which we define as the basic belief system or worldview that guides the investigator, not only in choices of method but in ontologically and epistemologically fundamental ways.”.

To protect research participant is an aim that can go further, through the establishment of research processes that involve research participants in all definitions about research and that promote empowerment of the vulnerable population ( as it is proposed by CBPR, for example), rather than just protect them in a paternalistic way.

When the duty to obtain written informed consent from each research participant was established, in a historical moment when people were involved in research without their IC and it results in damage for them, it was revolutionary. Nowadays, when there are researchers that include among their responsibilities to change the unfair situations and promote social justice, empowering research participants in a way that they can promote the necessary changes, the focus on written IC becomes insufficient. And, even worst, because the hegemony of positivist paradigms, even when the proposal is to achieve social justice, some RECs continuous to ask IC to be signed by those who already became coauthors of the research project.

It is fundamental that everyone who participates in the production of research ethics guidelines and REC members recognize that there are different ways to conduct research with human beings, which are related with different values and that these differences result in specific ethical aspects to be considered.

Then it is needed to bring the discussion about research and ethics in the political sphere that makes up the scientific field. But as times goes by and the plurality of research grows, the scientific field must move to a more democratic and open field were agreements can be constructed to develop a more productive relation between different trends and researchers. We don't believe in the construction of consensus, but rather in evolving and changing agreements that can give openness to diversity and fairness for the development of different scientific movements and trends. This doesn't mean the end of confrontation and debate, maybe is the opposite: to generate better conditions for the negotiation of them.

Finally, we should remember that the discussion of ethics in research must not be reduced to norms and codes, which makes it a heteronomous issue. Ethics in research should begin by recognizing that the researcher is a moral subject, and therefore its practices are morals ones. Moral reflections, that is, ethics, should be a core process of every researcher, recognizing that morality is also a human capacity that must be developed. As Freire ${ }^{41}$ stated for coherence between our thoughts and actions, morality should also be understood as a lighthouse, a goal to be obtained, rather than a definitive milestone. Following Freire, this goal requires grate effort and constant reflection, and can be fostered if there is an environment of discussion and critical analysis. 


\section{Collaborations}

ICZ Guerriero and FP Correa participated on an equal basis in all the preparatory stages of this article.

\section{Referências}

1. Guerriero ICZ. The challenge to write specific guidelines on research ethics in Social Science and Humanities, in Brazil. Revista Salud Pública Universidad de Antioquia. In press 2015.

2. Bourdieu P. The specificity of the scientific field and the social conditions of the progress of reason. Social Science Information 1975; 14:19-47.

3. São Paulo. Health Department of the City. Meeting on Ethics in Qualitative Health Research. Report. Iara Coelho Zito Guerriero, coordenadora. São Paulo, 2007. [accessed 2015 Mar 30]. Available at: http:// www.prefeitura.sp.gov.br/cidade/secretarias/upload/ saude/arquivos/comiteetica/Report_Ethics_Qualitative_Health_Research_2008.PDF

4. Brasil. Ministério da Saúde (MS). Conselho Nacional de Saúde. Resolução no 196 de 10 de outubro de 1996. Diretrizes e Normas Regulamentadoras de Pesquisas Envolvendo Seres Humanos. Diário Oficial da União 1996; 16 out.

5. Brasil. Ministério da Saúde (MS). Conselho Nacional de Saúde. Resolução no 466, de 12 de dezembro de 2012. Diário Oficial da União 2013; 13 jun.

6. National Commission on Research Ethics (CONEP). Letter sent to the WG SSH. 28 January 2015.

7. Guerriero IZC, ML Bosi. Research ethics in the dinamic of scientific field: notes about the construction of guidelines for Social Science and Humanities. Cien Saude Colet. 2015; 20(9):2615-2624.

8. Guba EG, Lincoln YS. Competing Paradigms in Qualitative Research. In: Denzin NK, Lincoln YS, editors. Handbook of qualitative research. Thousand Oaks: Sage; 1994. p. 105-117.

9. Lincoln YS, Lynham SA, Guba EG. Paradigmatic controversies, contradictions, and emerging confluences, revised. In: Denzin NK, Lincoln YS, editors. The Sage Handbok of Qualitative Research. Thousand Oaks: Sage; 2011. p. 97-128.

10. Silva FL. Methodological procedures and ethical decisions. Cien Saude Colet 2008; 13(2):324-326.

11. Cortina A, Martínez E. Ética. 2nd ed. Madrid: Ediciones Akal; 1998.

12. Sandel M. Justice. What's the Right Thing to Do? New York: Farrar, Straus and Giroux; 2009.

13. Pieper A. Ética y Moral. Barcelona: Crítica; 1991.

14. Tugendhat E. Lecciones de ética. Barcelona: Gedisa; 1997.

15. Berger P, Luckmann T. La construcción social de la realidad. Buenos Aires: Amorrortu; 1968.

16. Bauman, Z. Ética posmoderna. Mexico: Siglo XXI de España; 2006.

17. Kohlberg L. Psicología del desarrollo moral. Bilbao: Descleé de Brouwer; 1992

18. Schwandt T. Three epistemological stances for qualitative inquiry. In: Denzin N, Lincoln Y, editors. Handbook of qualitative research. $2^{\text {nd }}$ Edition. Thoudand Oaks: Sage; 2000. p. 189-214

19. Popper K. The Logic of the Social Sciences. 1976 [accessed 2015 mar 30]. Available from: http://www. autodidactproject.org/other/positivismusstreit/popper_logic.html

20. Habermas J. Teoría de la acción comunicativa. Madrid: Taurus; 1987. 
21. Denzin N, Giardina M. Qualitative inquiry and social justice: Toward a politics of hope. In: Denzin N, Giardina M, organizers. Qualitative Inquiry and Social Justice. Walnut Creek: Left Coast; 2009. p. 11-50.

22. Lyotard J. La condición postmoderna: Informe sobre el saber. Madrid: Cátedra; 2006.

23. Feser E. Robert Nozick (1938 - 2002). Internet Encyclopedia of Philosophy. [accessed 2015 mar 30]. Available from: http://www.iep.utm.edu/nozick/

24. Hernández M. Desigualdad, inequidad e injusticia en el debate actual en salud: posiciones e implicaciones. Taller Latinoamericano de Determinantes Sociales de la Salud. Asociación Latinoamericana de Medicina Social (ALAMES), 29 de septiembre a 2 octubre de 2008 , México DF, México.

25. Rawls J. El liberalismo político. Mexico: Fondo de Cultura Económica; 1995

26. Sen A. La idea de la justicia. México: Taurus; 2010

27. Siqueira R, Schramm FR. A saúde entre a iniquidade e a justiça: contribuições da igualdade complexa de Amartya Sen. Cien Saude Colet 2005; 10(1):129-142.

28. Garrafa V. Ampliação e politização do conceito internacional de bioética Rev Bioét 2012; 20(1):9-20

29. Macena A, Veloso G. Bioética: uma crítica ao principialismo. Derecho \& Cambio Social 2009 [accessed 2015 mar 30]; 6(17). Available from: http://www.derechoycambiosocial.com/revista017/bioetica.htm

30. Maldonado C. Crisis of bioethics and bioethics in the midst of crises. Rev Latinoam Bioét 2012; 12(22):112 123.

31. Venkatapuram V, Marmot M. Epidemiology and social justice in light of social determinants of health research. Bioethics 2009; 23(2):79-89.

32. Venkatapuram S. Health justice. An argument from the capabilities approach. Cambridge: Polity Press; 2011.

33. Lincoln YS. Emerging Criteria for Quality in Qualitative and Interpretive Research. Qualitative Inquiry 1995; 1(3):275-289.
34. World Health Organization (WHO). Commission on social determinants of health. Towards a conceptual framework for analysis and action on the social determinants of health. Geneva: WHO; 2005.

35. Granda E. El saber en salud pública en un ámbito de pérdida de antropocentrismo y ante una visión de equilibrio ecológico. Rev Fac Nac Salud Pública 2007; 26(5):65-90.

36. Campos G, Cunha G, Figueiredo M. Práxis e formação Paideia: apoio e cogestão em saúde. São Paulo: Hucitec; 2013.

37. Breilh J. Epidemiología crítica. Ciencia emancipadora e interculturalidad. Buenos Aires: Lugar Editorial; 2003.

38. Guerriero ICZ, Dallari SG. The need for adequate ethical guidelines for qualitative health research. Cien Saude Colet 2008; 13(2):303-311.

39. Bosk C, Devries R. Bureaucracies of mass deception: IRBs and the ethics of ethnographic research. Annals of the American Academy of Politic and Social Sciences 2004; 595:249-263.

40. Minkler M, Wallerstein N, editors. Community-Based Participatory Research for Health: From Process to Outcome. $2^{\text {nd }}$ ed. San Francisco: John Wiley \& Sons; 2008.

41. Freire P. Pedagogía de la autonomía: Saberes necesarios para la práctica educativa. México: Siglo XXI; 2006.

Artigo apresentado em 10/04/2015

Aprovado em 04/05/2015

Versão final apresentada em 06/05/2015 